Вывод: При объединении коммуникационных и информационных технологий образовался термин «информационно-коммуникационные технологии». При изучении влияния информационных трендов на информационно-коммуникационные технологии показало, с их помощью особое внимание уделяется коммуникационным процессам, которые отвечают за взаимодействие потребителей и их информационное обслуживание.

$$
* * *
$$

1. Осенний В.В., Трубилин М.Е. Современные информационные технологии в системе точного земледелия // Научное обеспечение агропромышленного комплекса. Сборник статей по материалам X Всероссийской конференции молодых ученых, посвященной 120-летию И.С. Косенко. Отв. за вып. А. Г. Кощаев. - 2017. C. $442-443$.

2. Информационные ресурсы и технологии в экономике: Учебное пособие / Под ред. Романова А.Н.. - М.: Вузовский учебник, 2018. - 319 с.

3. Ивасенко, А.Г. Информационные технологии в экономике и управлении: Учебное пособие / А.Г. Ивасенко, А.Ю. Гридасов, В.А. Павленко. - М.: КноРус, 2018. - 288 с.

4. Коршунова, Е.Д. Экономика, организация и управление промышленным предприятием: Учебник / Е.Д. Коршунова, О.В. Попова, И.Н. Дорожкин. - М.: Курс, 2018. - 272 с.

5. Краскова А. А. Оценка инвестиционной привлекательности предприятий АПК с использованием информационных технологий / А. А. Краскова, В. В. Осенний, Н. М. Гудимова // Научно-методический электронный журнал Концепт. - 2015. - № 6. - С. 31-35.

\title{
Дружинин П.В. \\ Концентрация ресурсов в столице региона и ее последствия
}

Карельский научный изентр РАН (Россия, Петрозаводск)

doi: 10.18411/trnio-11-2021-98

\section{Аннотация}

В статье исследуется влияние концентрации ресурсов в столице региона на развитие экономики региона в целом. Проблема состоит в том, что переток населения, в первую очередь молодежь, в столицу региона позволяет ей более успешно развиваться, но одновременно периферия теряет наиболее качественный человеческий капитал. Изучалась взаимосвязь показателей, характеризующих концентрацию населения в столице региона и развитие экономики региона в целом. Показано отсутствие положительного влияния концентрации населения в столице региона на основные показатели региональной экономики.

Ключевые слова: рост экономики региона, столица региона, концентрация населения.

\section{Abstract}

The article examines the influence of the concentration of resources in the capital of the region on the development of the region's economy as a whole. The problem is that the flow of the population, primarily young people, to the regional capital allows it to develop more successfully, but at the same time the periphery is losing the highest quality human capital. The interrelation of indicators characterizing the concentration of the population in the capital of the region and the development of the regional economy as a whole was studied. The absence of a positive influence of the concentration of the population in the capital of the region on the main indicators of the regional economy is shown.

Keyword: regional economic growth, regional capital, population concentration.

Столицы большинства российских регионов успешно развиваются, в то время как периферия этих регионов теряет ресурсы, в первую очередь человеческий капитал. Население, в первую очередь молодежь переезжает в столицу своего региона или более 
развитого региона. Зубаревич Н.В. показала, что размер города важен для его привлекательности, но также способствует его росту статус региональной столицы, экономическая специализация, географическое положение и реализация в регионе крупных федеральных проектов [1].

Наиболее активная миграция идет в Москву и Санкт-Петербург, крупнейшие города страны. Другие агломерации растут медленно или даже население в них сокращается. Существуют серьезные институциональные барьеры для реализации в РФ «агломерационного эффекта» [2]. Необходимо создавать условия для развития крупнейших городов, как точек инновационного роста и одновременно уменьшать территориальные диспропорции [3; 4]. Развитие малых и средних городов может дополнять столичную агломерацию, заполняя ниши, которые невыгодно развивать в крупном городе [5]. В то же время необходимо диверсифицировать экономику моногородов [6].

В связи с концентрацией ресурсов в региональной столице возникает вопрос об эффективности этого процесса, как меняются социально-экономические показатели региона в целом. Миграция молодежи с периферии ведет к росту доли старших поколений, имеющих опыт и знания для работы в лишь традиционных отраслях экономики. Поэтому необходимо исследовать, как влияет концентрация ресурсов в столице региона на развитие региона в целом. Данное исследование проводилось в рамках госзадания КарНЦ РАН.

На основе данных Росстата за 1990-2019 гг. анализировалось изменение валового регионального продукта (ВРП), его структуры, промышленного производства, занятости, инвестиций и других показателей. Регион разбивался на две части - столица и периферия, для которых определялось изменение численности населения и доля столицы с 1998 по 2019 гг. Рассматривался уровень концентрации населения (доля населения в столице региона) в 1997 и 2019 гг., и рост концентрации (отношение доли населения региона в столице региона в 2019 г. к доле в 1997 г.).

Рост населения столицы региона немного зависит от численности его населения, чем больше город, тем быстрее он растет, хотя связь очень слабая $(\mathrm{R}=0,24)$, в то же время связь численности населения с ростом концентрации еще менее значима и отрицательна $(\mathrm{R}=-0,19)$. Рост концентрации населения редко ведет к росту населения столице региона, поскольку население большинства регионов снижается.

Динамику развития экономики региона часто определяют по росту ВРП. Если рассматривать концентрацию населения региона в его столице в 1997 г., перед началом экономического роста, то ее влияние на динамику ВРП за 1997-2019 гг. отсутствует, коэффициент корреляции отрицателен и близок к нулю. Причем, если не учитывать две крупнейшие агломерации Москвы и Санкт-Петербурга, то по оставшимся 75 регионам наблюдается скорее слабая отрицательная связь $(\mathrm{R}=-0,23)$.

Связь роста уровня концентрации населения в столице региона и роста ВРП также отсутствует. Значит, экономика регионов с более высоким уровнем концентрации населения в столице региона и с растущей концентрацией, не растет быстрее остальных, а, скорее всего, даже медленнее.

Более интересно рассмотреть влияние развития региональных столиц на эффективность роста региональной экономики - динамику ВРП на душу населения. Анализ данных показывает, что концентрация населения региона в его столице в 1997 г. и в 2019 г. никак не влияет на рост ВРП на душу населения за рассматриваемый период, коэффициент корреляции отрицателен и близок к нулю. Причем, без учета Москвы и Санкт-Петербурга по оставшимся 75 регионам результаты ухудшаются, значит, регионы с более высокой концентрацией населения не были отмечены более высоким ростом эффективности. Рост концентрации населения в столице региона также не ведет к ускорению роста ВРП на душу населения.

Анализ данных по всем 77 регионам показал, что величина ВРП на душу населения в 2019 г. никак не связана с концентрацией населения региона в его столице ни в 1997 г., ни в 2019 г. Значит концентрация населения региона в его центре не оказывает положительного 
влияния на эффективность региональной экономики. Кажется, что рост концентрации населения связан с ВРП на душу населения $(\mathrm{R}=0,54)$, и население наиболее активно переезжало в столицы более эффективных регионов. Но если выделить эти более эффективные регионы, то ими оказываются северные добывающие и если их не учитывать, то выявленная зависимость исчезает. Надо отметить, что в данных регионах (исключая Тюменскую область) население быстро сокращается, значит рост концентрации в них происходит за счет оттока населения с периферии в другие регионы.

Лишь для 13 регионов, имеющих крупнейшие агломерации, есть заметная связь роста концентрации населения в столице региона с ВРП на душу населения $(\mathrm{R}=0,62)$.

Анализ других показателей подтвердил вывод об отсутствии эффекта от концентрации населения региона в его столице. Зависимости динамики ВРП и ВРП на душу населения от доли столицы региона в численности занятых нет. Зависимость динамики ВРП и ВРП на душу населения от доли столицы региона в объеме инвестиций региона также не наблюдается.

Выводы. Анализ данных по российским регионам показал, что уровень концентрации населения в столице региона практически не влияет на развитие экономики региона. Регионы с более высоким уровнем концентрации не растут быстрее других, они не имеют более высокой эффективности экономики и она не растет быстрее, чем у других регионов. Рост концентрации населения в региональной столице не влияет на рост экономики региона и ее эффективности. Лишь у крупнейших агломераций быстрее растет концентрация населения в наиболее эффективных регионах.

Публикация подготовлена в рамках госзадания КарНЦ РАН.

$$
* * *
$$

1. Зубаревич Н.В. Развитие крупных городов России: только ли размер имеет значение? / Экономика и география. Санкт-Петербург, 2013. С.198-210.

2. Зубаревич Н.В. Роль «агломерационного эффекта» в социально-экономическом развитии крупных городов России / География, градостроительство, архитектура: синтез наук и практик. Смоленск, 2013. С.191-207.

3. Кузнецова О. Возрастающая роль городов-миллионеров: опыт Германии в контексте российских проблем // Федерализм. 2018. №4. С.37-50.

4. Кузнецова О.В. Городские агломерации и СПР // Регионалистика. 2020. №3. С.67-70.

5. Лаппо Г.М. Города России: взгляд географа. М.: Новый хронограф, 2012. 503 с.

6. Баранов Д.Н. Современные тенденции развития экономики городских агломераций. Саратов: Вузовское образование, 2015. 188 с.

\section{Жегера К.В., Крашенинникова И.Д. \\ Анализ конкурентоспособности предприятий по производству сельскохозяйственной техники в Пензенской области}

Пензенский государственный университет архитектуры и строительства

(Россия, Пенза)

doi: 10.18411/trnio-11-2021-99

\section{Аннотация}

Сельское хозяйство - это одна из крупных и наиболее важных отраслей экономики России, являющаяся основным поставщиком сырья. Рассмотрев предприятия Пензенской области, занимающиеся производством сельскохозяйственной техники, выделены три наиболее крупных: АО «Радиозавод», ООО «Агро Комплект» и АО «Белинсксельмаш». Для сравнения между собой и определения наиболее конкурентного производителя в рассматриваемой области применен ФСА-анализ.

Ключевые слова: сельскохозяйственная продукция, конкурентоспособность, сеялка, ФСА-анализ, комплексный приоритет. 